\title{
APLIKASI FORECASTING PENJUALAN KERAJINAN BATU MENGGUNAKAN METODE LINEAR REGRESSION (STUDI KASUS PADA CV. BUKIT MULIA)
}

\author{
Tenti Pristiani, Mira Orisa, Febriana Santi Wahyuni \\ Program Studi Teknik Informatika S1, Fakultas Teknologi Industri \\ Institut Teknologi Nasional Malang, Jalan Raya Karanglo km 2 Malang, Indonesia \\ 1718077@scholar.itn.ac.id
}

\begin{abstract}
ABSTRAK
Forecasting atau prediksi telah menjadi salah satu pertimbangan dalam kehidupan manusia, khususnya dalam bidang bisnis dan ekonomi. Dengan adanya forecasting, kerugian perusahaan dapat diminimalisir semaksimal mungkin sedangkan keuntungan dapat dimaksimalkan. Sejauh ini proses penjualan di CV. Bukit Mulia masih berbasis rekapitulasi manual dan belum menerapkan forecasting untuk transaksi penjualan produknya. Berdasarkan hal tersebut, peneliti menggagas sebuah aplikasi forecasting penjualan berbasis website untuk memudahkan CV. Bukit Mulia dalam memonitoring sistem pada saat melakukan aktivitas bisnis di luar perusahaan dan memprediksi penjualan pada tahun yang akan datang. Penelitian ini merupakan solusi yang memudahkan Pemilik CV. Bukit Mulia dalam memprediksi penjualan kerajinan batu berbasis website. Metode yang digunakan dalam prediksi penjualan ini adalah Metode Linear Regression. Kebutuhan produk skripsi yang dikembangkan mencakup data penjualan kerajinan batu pada tahun 2017-2019 serta kemungkinan pengguna aplikasi untuk mengetahui prediksi jumlah penjualan kerajinan batu dan untuk memudahkan pemilik dalam mengolah data. Hasil penelitian ini adalah berupa aplikasi forecasting penjualan kerajinan batu berbasis website. Produk mempunyai fitur pendataan batu, pendataan kerajinan batu, pendataan data penjualan, dan forecasting penjualan. Berdasarkan pengujian terhadap fitur - fitur pada aplikasi forecasting adalah seluruhnya dapat berjalan dengan baik. Berdasarkan pengujian pengguna diketahui mayoritas pengguna memahami dan menggunakan fitur pada aplikasi forecasting penjualan kerajinan batu berbasis website. Berdasarkan hasil penelitian dapat disimpulkan bahwa aplikasi yang dikembangkan dapat memudahkan pimpinan dalam mengolah data dan memprediksi penjualan kerajinan batu.
\end{abstract}

\section{Kata Kunci : Forecasting, Prediksi, Penjualan, Linear Regression}

\section{PENDAHULUAN}

Prediksi (forecasting) penjualan adalah taksiran penjualan yang akan datang dari usaha atau produk suatu perusahaan [1]. Prediksi telah dijadikan salah satu pertimbangan terutama dalam bidang bisnis dan ekonomi, agar kerugian suatu perusahaan dapat diminimalisir dan keuntungan dapat dimaksimalkan [2]. Dengan melakukan prediksi maka perusahaan dapat memprediksi jumlah penjualan pada periode selanjutnya berdasarkan hasil data penjualan yang lalu, sehingga dapat melihat peluar penjualan yang ada dipasar [2].

CV. Bukit Mulia adalah sebuah perusahaan yang bergerak di bidang industri kerajinan batu seperti memproduksi berbagai macam kerajinan seperti meja, kursi, asbak, dan lain sebagainya. Berdasarkan wawancara kepada owner CV. Bukit Mulia selaku narasumber diketahui bahwa masalah yang dihadapi adalah proses input data penjualan perusahaan masih bersifat manual bisa saja penyusunan laporan terjadi kesalahan yang dilakukan oleh manusia (human error) [3].

Untuk mengurangi kesalahan data diperlukan sistem terkomputerisasi untuk memprediksi penjualan dan memudahkan penginputan data penjualan berbasis website. Metode yang digunakan dalam prediksi penjualan ini adalah metode prediksi Linear Regression (Regresi Linier). Dengan metode ini dalam memprediksi penjualan kerajinan batu dapat mengetahui mengalami penaikan atau penurunan penjualan ditahun - tahun berikutnya [4].

Berdasarkan paparan tersebut, diketahui di CV. Bukit Mulia masih belum menerapkan forecasting untuk transaksi penjualan. Oleh karena itu, peneliti melalui penelitian ini bermaksud membuat aplikasi forecasting penjualan kerajinan batu menggunakan metode linear regression yang bertujuan untuk mengetahui prediksi jumlah penjualan kerajinan batu dan untuk memudahkan pemilik dalam mengolah data.

\section{TINJAUAN PUSTAKA}

\subsection{Penelitian Terdahulu}

Menurut Penelitian Ayuni dan Fitrianah yang berjudul "Penerapan Metode Regresi Linier Untuk Prediksi Penjualan Properti pada PT XYZ", penelitian ini bertujuan untuk mendapatkan prediksi penjualan properti berdasarkan data penjualan properti pada PT XYZ. Dalam metode regresi linier, variabel yang digunakan adalah kuantiti atau jumlah property yang terjual sebagai variabel akibat sedangkan periode penjualan sebagai variabel penyebab. Untuk menguji keakuratan prediksi menggunakan MSE, RMSE, dan MAPE. Prediksi tersebut tergolong sangat baik karena semua jenis uji akurasi menghasilkan nilai yang memenuhi kriteria [2]. 
Menurut Penelitian Haryana dan Iswahyudi yang berjudul "Teknik Prediksi Penjualan Sepeda Motor dengan Menggunakan Metode Regresi Linier Sederhana pada CV. Niaga Pratama Motor", penelitian ini bertujuan untuk memprediksi penjualan sepeda motor Yamaha dan memperbaiki jadwal rutin detail perusahaan. Pengelolaan data dan informasi mendorong kinerja karyawan dalam proses pelanyanan, sehingga dapat dilaksanakan secara efektif dan efisien. Berdasarkan data penjualan CV. Niaga Pratama Motor selama periode Januari Desember 2014 cocok untuk penggunaan Metode linier regresi sederhana [5].

Menurut Penelitian Marbun dkk yang berjudul "Perancangan Sistem Peprediksi Jumlah Wisatawan Asing", penelitian ini bertujuan untuk memprediksi jumlah wisatawan asing yang berkunjung ke Sumatera Utara dengan menggunakan pemodelan Unified Modelling Language (UML). Berdasarkan data 10 tahun terakhir dari 2006 sampai 2015 didasarkan bulan yang akan diprediksi. Dalam memprediksi jumlah wisatawan menggunakan metode regresi linier, pada proses perhitungan diperoleh persamaan akhir $\hat{Y}=a$ $+b(X)$ variabel $Y$ adalah hasil prediksi dan variabel $\mathrm{X}$ adalah periode prediksi.. Hasil yang diperoleh pada Januari 2016 adalah 16.937 [6].

Menurut Penelitian Harliana dan Syafrianto pada penelitiannya yang berjudul "Prediksi Jumlah Pendaftaran Calon Mahasiswa Baru dengan Metode Regresi Linier", penelitian ini bertujuan untuk memprediksi jumlah mahasiswa baru yang mendaftar pada tahun ajaran berikutnya menggunakan metode regresi linier. Dengan menggunakan data 6 tahun terakhir, variabel yang digunkana dalam penelitian ini adalah tahun ajaran sebagai variabel penyebebab dan jumlah calon mahasiswa baru sebagai variabel akibat. Berdasarkan persamaan regresi linier Strata-1 $\hat{Y}=$ $104.600+2.829 \mathrm{X}$ diperoleh 124 calon mahasiswa baru untuk S-1 dan persamaan regresi linier DiplomaIII $\hat{\mathrm{Y}}=53.734+10.776 \mathrm{X}$ diperoleh 128 calon mahasiswa baru D-III [7].

Menurut Pemelitian Katemba dan Djoh yang berjudul "Prediksi Tingkat Produksi Kopi Menggunakan Regresi Linier", penelitian ini bertujuan untuk mengetahui apakah produksi kopi meningkat atau menurun dari periode ke periode. Untuk memenuhi permintaan digunakan digunakan regresi linier untuk memprediksi karakteristik kualitas dan kuantitas dalam produksi. Dengan menggunakan metode regresi linier untuk melakukan prediksi dapat memberikan informasi yang membantu petanii dan pemerintah dalam menyusun kebijakan peningkatan produksi kopi Kabupaten Manggarai. Untuk menghitung akurasi prediksi produksi kopi dilakukan pengujian dengan MSE dan MAPE [4].

\subsection{Data Mining}

Data Mining adalah suatu proses penggalian data dan informasi yang prosesnya tidak diketahui sebelumnya, tetapi dapat dipahami sebagai pengambilan keputusan yang sangat penting. Penambangan data menggambarkan serangkaian teknik yang bertujuan untuk menemukan pola yang sebelumnya tidak diketahui. Data mining merupakan bagian dari proses KDD (Knowledge Discovery in Database), yang meliputi beberapa tahapan yaitu pemilihan data, preprocessing, tranformasi, data mining dan evaluasi hasil [8].

\subsection{Metode Linear Regression}

Metode Linear Regression adalah metode statistik paling sederhana yang digunakan untuk melakukan prediksi dengan menetapkan hubungan matematis antara variabel terikat $(\mathrm{Y})$ dan variabel bebas (X). Kedua variabel ini dianalisis sebagai forecasting dengan menggunakan metode linear regression. Jika variabel bebas diketahui, nilai variabel terikat dapat diprediksi biasanya penjualan atau permintaan produk dinyatakan sebagai variabel bebas yang lebih besar atau nilainya dipengaruhi oleh variabel terikat [2].

Metode linear regression merupakan salah satu metode yang digunakan untuk memprediksi karakteristik dalam segi kualitas maupun kuantitas. Hal ini dikarenakan dengan mengestimasi berbagai kombinasi produk, perusahaan dapat memperkirakan volume prediksi yang tepat [2]. Untuk mencari nilai prediksi dapat menggunakan rumus pada persamaan 2.1, persamaan 2.2, dan persamaan 2.3

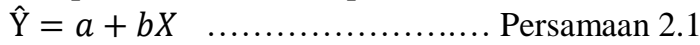

$a=\frac{\left(\sum Y\right)\left(\sum X^{2}\right)-\left(\sum X\right)\left(\sum X Y\right)}{n\left(\sum X^{2}\right)-\left(\sum X\right)^{2}} \ldots \ldots \ldots \ldots . .$. Persamaan 2.2

$b=\frac{n\left(\sum X Y\right)-\left(\sum X\right)(\Sigma Y)}{n\left(\sum X^{2}\right)-\left(\sum X\right)^{2}} \ldots \ldots \ldots \ldots \ldots . . .$. Persamaan 2.3

Keteranagn Variabel :

$\hat{Y}=$ Hasil prediksi

$Y=$ Variabel terikat

$X=$ Variabel bebas

$a=$ Konstanta

$b=$ Koefisien regresi

$\boldsymbol{n}=$ Jumlah data

\subsection{Pengujian Keakurasian}

Keakurasian prediksi dapat ditentukan dari banyaknya kesalahan (error) yang terjadi antara data prediksi dengan data aktual. Pengujian keakurasian digunakan untuk memastikan tingkat akurasi dari hasil prediksi yang telah dibuat. Pengujian keakurasian dilakukan karena semua kondisi prediksi yang dilakukan selalu memiliki tingkat ketidakpastian tertentu. Ketidakpastian yang diperoleh terjadi karena tidak ada ketidakpastian yang akurat saat memprediksi hasil yang diperoleh. Jika tingkat kesalahan metode prediksi kecil, metode tersebut dianggap baik [9]. Berbagai cara untuk menghitung besarnya kesalahan (error) yaitu :

a. MSE (Mean Squared Error)

Menurut Pakaja (2012), Mean Squared Error (MSE) merupakan salah satu metode evaluasi metode prediksi. Kuadaratkan setiap kesalahan 
atau sisa dan tambahkan jumlahnya ke observasi. MSE adalah rata-rata selisih kuadrat antara nilai prediksi dan nilai observasi. Kekurangan menggunkan MSE adalah cenderung memperburuk deviasi yang lebih besar karena kuadrat [10]. Untuk menghitung nilai MSE dapat menggunakan rumus pada persamaan 2.6 :

$$
M S E=\frac{1}{n} \sum_{t=1}^{n}\left(Y_{t}-\hat{Y}_{t}\right)^{2} \ldots . . \text { Persamaan } 2.4
$$

Keterangan variabel :

$Y_{t}=$ Nilai aktual pada periode $\mathrm{t}$

$\hat{Y}_{t}=$ Nilai prediksi pada periode $\mathrm{t}$

$n=$ Jumlah data

\section{b. RMSE (Root Mean Square Error)}

Root Mean Square Error (RMSE) merupakan pengakaran dari nilai MSE yang diperoleh sebelumnya. RMSE digunakan untuk mencari nilai akurasi hasil prediksi data masa lalu menggunakan rumus (Makridakis, 1999). Semakin kecil nilai yang diperoleh semakin baik hasil prediksi. Untuk menghitung nilai RMSE dapat menggunakan rumus pada persamaan 2.5 :

$R M S E=\sqrt{\frac{1}{n} \sum_{t=1}^{n}\left(Y_{t}-\hat{Y}_{t}\right)^{2}} .$. Persamaan 2.5

Keterangan variabel :

$Y_{t}=$ Nilai aktual pada periode $\mathrm{t}$

$\widehat{Y}_{t}=$ Nilai prediksi pada periode $\mathrm{t}$

$n$ = Jumlah data

c. MAPE (Mean Absolute Percentage Error)

Menurut Pakaja (2012), Mean Absolute Percentage Error (MAPE) adalah mengukur nilai kesalahan (error) dengan menghitung persentasi deviasi antara data aktual dan data prediksi. MAPE dapat dihitung dengan membagi nilai kesalahan (error) absolut di setiap periode kemudian dibagi dengan nilai aktual untuk periode tersebut. Kemudian, merata-rata persentase kesalahannya. Jika nilai MAPE kurang dari 10\% maka hasil prediksi dianggap sangat baik, jika nilai MAPE kurang dari 20\% maka hasil prediksi dianggap baik [10]. Untuk menghitung nilai MAPE dapat menggunakan rumus pada persamaan 2.6:

MAPE $\frac{1}{n} \sum_{t=1}^{n} \frac{\left|Y_{t}-P_{t}\right|}{Y_{t}} * 100 \%$ Persamaan 2.8

Keterangan variabel :

$Y_{t}=$ Nilai aktual pada periode $\mathrm{t}$

$\hat{Y}_{t}=$ Nilai prediksi pada periode $\mathrm{t}$

$n=$ Jumlah data

\section{METODE PENELITIAN}

\subsection{Sistem Diagram Blok}

Diagram blok adalah diagram dari sebuah sistem, pada gambar 1 dapat dijelaskan bahwa admin terhubung ke internet terlebih dahulu kemudian mengakses website untuk login selanjutnya admin dapat input data kedalam database, untuk melakukan prediksi admin dapat masuk ke halaman prediksi untuk melakukan perhitungan menggunakan metode linear regression. Hasil perhitungan adalah informasi prediksi yang dapat diakses oleh admin.

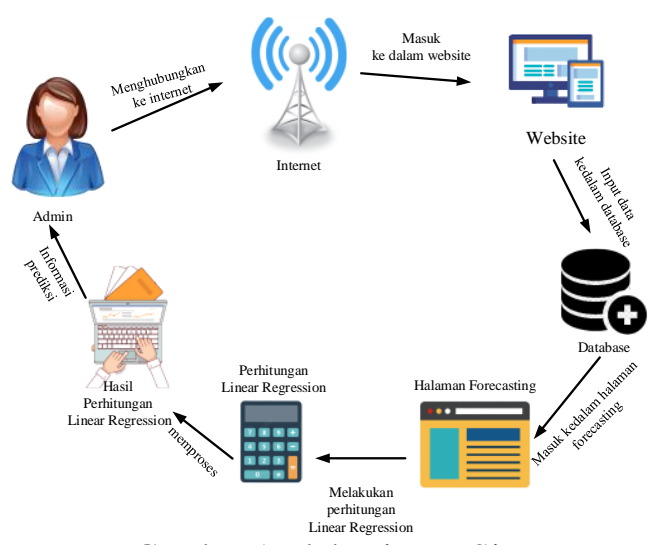

Gambar 1 Blok Digram Sistem

\subsection{Flowchart Sistem}

Flowchart sistem menggambarkan proses menjalankan aplikasi, seperti ditunjukkan pada Gambar 2.

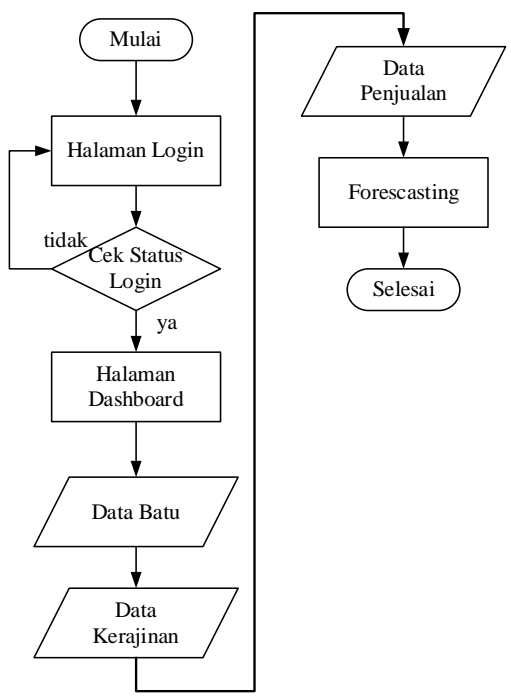

Gambar 2 Flowchart Sistem

Berdasarkan flowchart sistem pada Gambar 2, sistem dimulai dengan proses login pada halaman login, jika login tidak berhasil akan tetap berada dihalaman login, jika login berhasil maka akan masuk ke halaman admin. Selanjutnya admin dapat memasukkan data batu, data kerajinan, data penjualan dan dapat melakukan proses prediksi.

\subsection{Flowchart Metode Linear Regression}

Flowchart metode ini menjelaskan proses urutan sistem dari metode linear regression seperti ditunjukkan pada Gambar 3. 


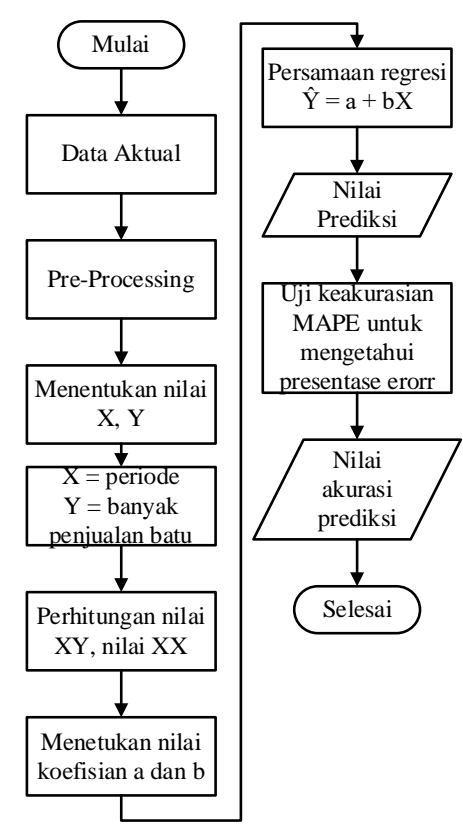

Gambar 3 Flowchart Metode Linear regression

Berdasarkan flowchart pada Gambar 3 Proses yang pertama kali proses pengumpulan data aktual yaitu data penjualan. Dari data aktual ke proses preprocessing mengeleminasi variabel yang tidak dibutuhkan, kemudian menentukan nilai $\mathrm{X}$ dan $\mathrm{Y}$ dimana $\mathrm{X}$ merupakan periode, dan $\mathrm{Y}$ merupakan jumlah penjualan jenis batu ke proses selanjutnya perhitungan nilai $\mathrm{XY}$ dan nilai $\mathrm{XX}$ kemudian menetukan nilai koefisien dari a dan $b$ sehingga diperoleh persamaan regresi. Dari nilai $\hat{Y}$ yang diperoleh menghitung persentase error menggunakan MAPE (Mean Absolute Percentage Error).

\section{HASIL DAN PEMBAHASAN}

\subsection{Halaman Login}

Pada halaman login diberikan hak akses admin untuk login. Admin harus memasukkan username dan password untuk masuk ke halaman utama admin. Tampilan halaman login dapat ditunjukkan pada Gambar 4.

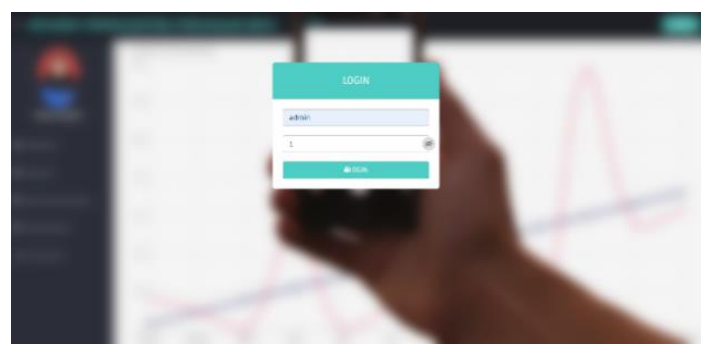

Gambar 4 Halaman Login

\subsection{Halaman Dashboard}

Pada halaman dashboard terdapat menu sidebar untuk masuk halaman data batu, data kerajinan batu, data penjualan dan forecasting. Halaman dashboard adalah halaman pertama kali diakses oleh admin Tampilan halaman admin dapat ditunjukkan pada gambar Gambar 5

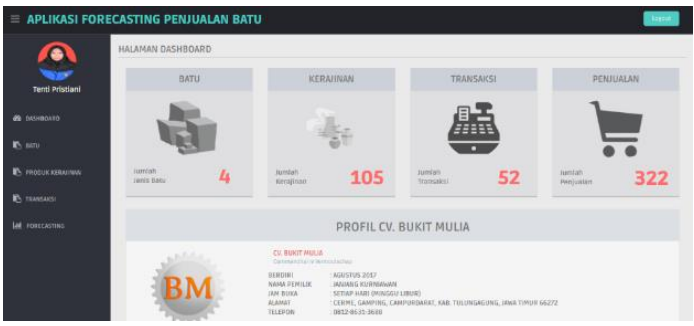

Gambar 5 Halaman Dashboard

\subsection{Halaman Data Batu}

Pada tampilan halaman kerajinan batu terdapat data kerajinan batu sehingga admin dapat melihat, menambahkan, mengubah, menghapus data batu. Tampilan halaman data batu dapat ditunjukkan pada Gambar 6.

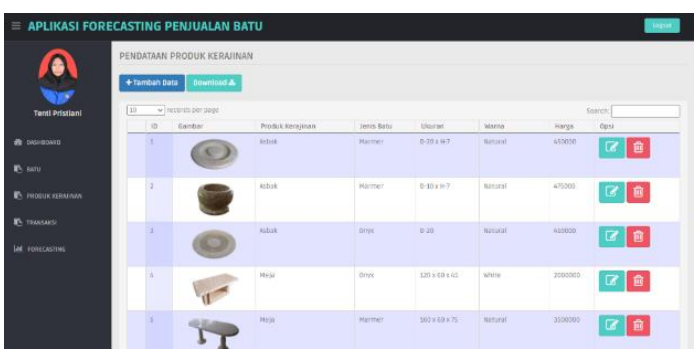

Gambar 6 Halaman Data Batu

\subsection{Halaman Kerajinan Batu}

Pada tampilan halaman kerajinan batu terdapat data kerajinan batu sehingga admin admin dapat melihat, menambahkan, mengubah, menghapus data kerajinan batu. Tampilan halaman data kerajinan batu dapat ditunjukkan pada Gambar 7.

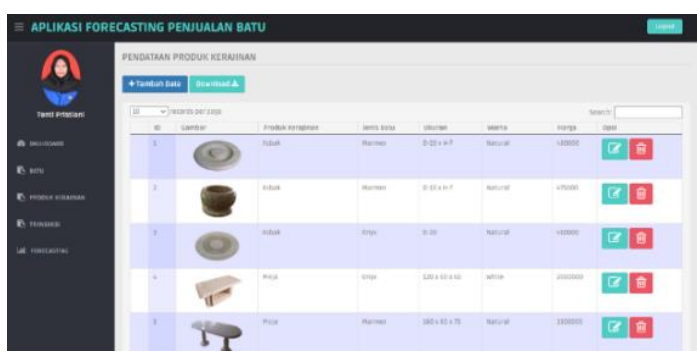

Gambar 7 Halaman Data Kerajinan Batu

\subsection{Halaman Transaksi}

Pada tampilan halaman transaksi terdapat data transaksi penjualan batu sehingga admin admin dapat melihat, menambahkan, menghapus data transaksi penjualan kerajinan. Tampilan halaman data transaksi penjualan kerajinan dapat ditunjukkan pada Gambar 8 . 


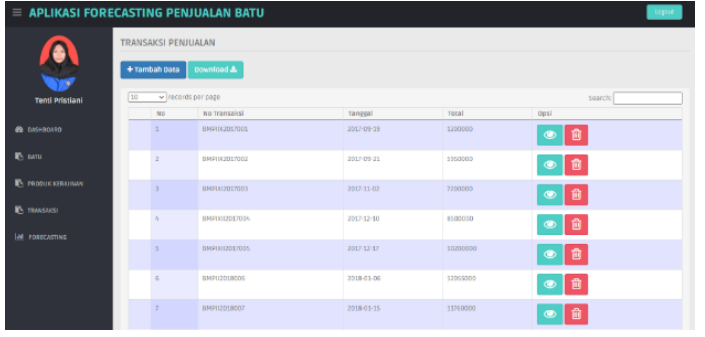

Gambar 8 Halaman Data Transaksi

\subsection{Halaman Forecasting}

Pada tampilan halaman forecasting admin dapat memprediksi penjualan dengan klik button hitung akan menampilkan perhitungan metode linear regression dan grafik. Tampilan halaman forecasting dapat ditunjukkan Gambar 9.

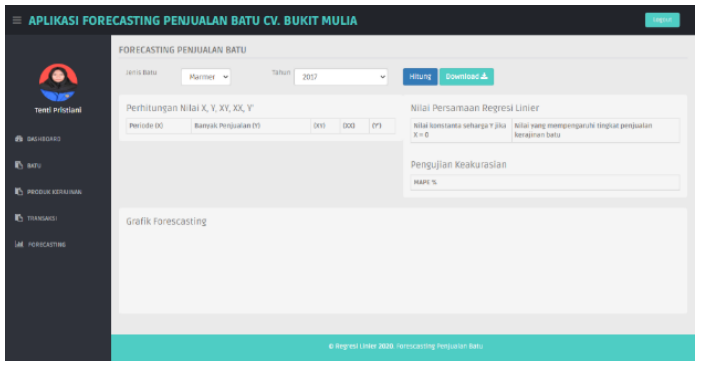

Gambar 9 Halaman Forecasting

\subsection{Perhitungan Metode Linear Regression}

Dalam perhitungan Metode Linear Regression penulis mengambil data pada tahun 2017-2019 pada CV. Bukit Mulia. Data yang diambil adalah data transaksi penjualan yang terjadi pada CV. Bukit Mulia.

\subsection{Batu Marmer}

Pada Tabel 1 data penjualan untuk jenis batu marmer, dengan nilai $\mathrm{X}$ kolom periode dan nilai $\mathrm{Y}$ banyaknya penjualan jenis batu marmer. Dengan menggunakan rumus pada persamaan 2.2 dan persamaan 2.3 didapat persamaan regresi $\hat{Y}=$ $-78.60+6.29 \mathrm{X}$ dengan nilai akurasi $5.08 \%$ menggunakan MAPE. Arti persamaan regresi tersebut adalah sebagai berikut :

1. Setiap kenaikan variabel $X$ (periode) maka akan menaikkan variabel Y (penjualan batu marmer) sebesar 6,29 satuan, dengan asumsi variabel lain bernilai tetap. Artinya setiap tahun penjualan batu marmer akan meningkat 6,29 satuan.

2. Apabila nilai variabel $X$ (periode) dianggap 0 maka penjualan baru marmer adalah $-78,60$ satuan (sebesar nilai konstantanya).

Tabel 1 Perhitungan Batu Marmer

\begin{tabular}{|c|c|c|c|c|c|}
\hline Periode & $\mathrm{X}$ & $\begin{array}{c}\text { Banyak } \\
(\mathrm{Y})\end{array}$ & $\mathrm{XY}$ & $\mathrm{XX}$ & $\hat{Y}=\mathrm{a}+\mathrm{bX}$ \\
\hline \multirow{5}{*}{2020} & 13 & 17 & 221 & 169 & 3.22 \\
\cline { 2 - 6 } & 14 & 10 & 140 & 196 & 9.51 \\
\cline { 2 - 6 } & 15 & 0 & 0 & 225 & 15.81 \\
\cline { 2 - 6 } & 16 & 52 & 832 & 256 & 22.10 \\
\cline { 2 - 6 } & 17 & 0 & 0 & 289 & 28.39 \\
\cline { 2 - 6 } & 18 & 15 & 270 & 324 & 34.69 \\
\cline { 2 - 6 } & & & & \\
\hline
\end{tabular}

\begin{tabular}{|c|c|c|c|c|c|}
\hline Periode & $\mathrm{X}$ & $\begin{array}{c}\text { Banyak } \\
(\mathrm{Y})\end{array}$ & $\mathrm{XY}$ & $\mathrm{XX}$ & $\hat{Y}=\mathrm{a}+\mathrm{bX}$ \\
\hline \multirow{6}{*}{} & 19 & 58 & 1102 & 361 & 40.98 \\
\cline { 2 - 6 } & 20 & 46 & 920 & 400 & 47.27 \\
\cline { 2 - 6 } & 21 & 0 & 0 & 441 & 53.57 \\
\cline { 2 - 6 } & 22 & 137 & 3014 & 484 & 59.86 \\
\cline { 2 - 6 } & 23 & 56 & 1288 & 529 & 66.16 \\
\cline { 2 - 6 } & 24 & 63 & 1512 & 576 & 72.45 \\
\hline Total & 222 & 454 & 9299 & 4250 & \multicolumn{4}{|c}{} \\
\hline
\end{tabular}

Melalui grafik pada Gambar 10 jika perbedaan keduanya yang tidak terlalu jauh untuk dijadikan indikasi jika prediksi menggunakan metode linear regression cukup akurat. Grafik yang dihasilkan mengalami kenaikan setiap tahun penjualan batu marmer sebesar 6,29 satuan.

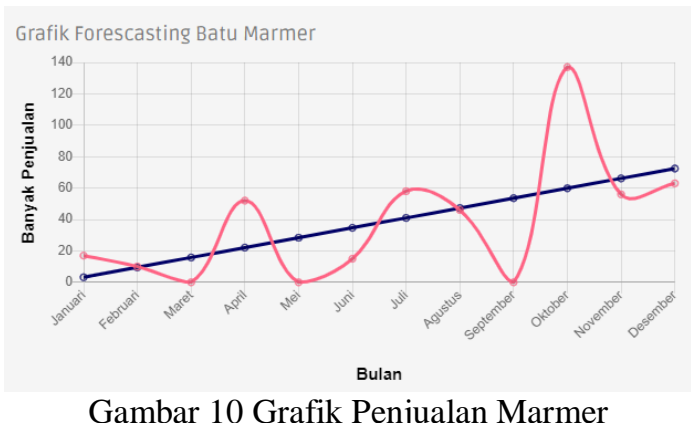

\subsection{Batu Onyx}

Pada Tabel 2 data penjualan untuk jenis batu onyx, dengan nilai $\mathrm{X}$ kolom periode dan nilai $\mathrm{Y}$ banyaknya penjualan jenis batu onyx. Dengan menggunakan rumus pada persamaan 2.2 dan persamaan 2.3 didapat persamaan regresi $\hat{Y}=$ $-0.33+0.13 X$ dengan nilai akurasi $6.46 \%$ menggunakan MAPE. Arti persamaan regresi tersebut adalah sebagai berikut :

1. Setiap kenaikan variabel $X$ (periode) maka akan menaikkan variabel Y (penjualan batu marmer) sebesar 0,13 satuan, dengan asumsi variabel lain bernilai tetap. Artinya setiap tahun penjualan batu marmer akan meningkat 0,13 satuan.

2. Apabila nilai variabel $X$ (periode) dianggap 0 maka penjualan baru marmer adalah -0,33 satuan (sebesar nilai konstantanya).

Tabel 2 Perhitungan Batu Onyx

\begin{tabular}{|c|c|c|c|c|c|}
\hline Periode & $\mathrm{X}$ & $\begin{array}{c}\text { Banyak } \\
(\mathrm{Y})\end{array}$ & $\mathrm{XY}$ & $\mathrm{XX}$ & $\hat{Y}=\mathrm{a}+\mathrm{bX}$ \\
\hline \multirow{5}{*}{} & 13 & 1 & 13 & 169 & 1.31 \\
\cline { 2 - 6 } & 14 & 1 & 14 & 196 & 1.43 \\
\cline { 2 - 6 } & 15 & 0 & 0 & 225 & 1.56 \\
\cline { 2 - 6 } & 16 & 1 & 16 & 256 & 1.69 \\
\cline { 2 - 6 } & 17 & 2 & 34 & 289 & 1.81 \\
\cline { 2 - 6 } & 18 & 3 & 54 & 324 & 1.94 \\
\cline { 2 - 6 } & 19 & 3 & 57 & 361 & 2.06 \\
\cline { 2 - 6 } & 20 & 9 & 180 & 400 & 2.19 \\
\cline { 2 - 6 } & 21 & 0 & 0 & 441 & 2.31 \\
\cline { 2 - 6 } & 22 & 1 & 22 & 484 & 2.44 \\
\cline { 2 - 6 } & 23 & 0 & 0 & 529 & 2.57 \\
\cline { 2 - 6 } & 24 & 3 & 72 & 576 & 2.69 \\
\hline Total & 222 & 24 & 462 & 4250 & \\
\hline
\end{tabular}


Melalui grafik pada Gambar 11 jika perbedaan keduanya yang tidak terlalu jauh untuk dijadikan indikasi jika prediksi menggunakan metode linear regression cukup akurat. Grafik yang dihasilkan mengalami kenaikan setiap tahun penjualan batu marmer sebesar 0,13 satuan.

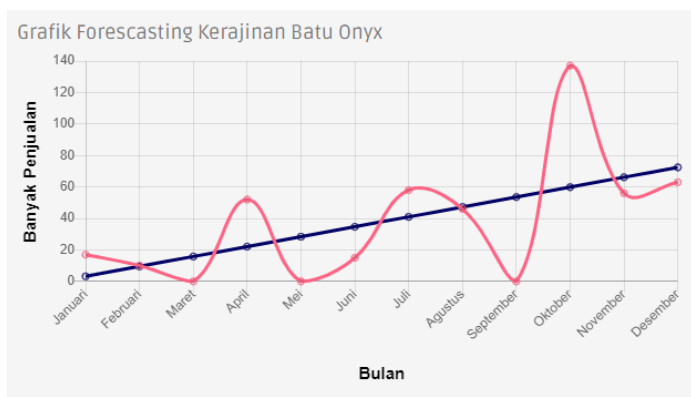

Gambar 11 Grafik Penjualan Onyx

\subsection{Batu Zeolite}

Pada Tabel 3 data penjualan untuk jenis batu zeolite, dengan nilai $\mathrm{X}$ kolom periode dan nilai $\mathrm{Y}$ banyaknya penjualan jenis batu zeolite. Dengan menggunakan rumus pada persamaan 2.2 dan persamaan 2.3 didapat persamaan regresi $\hat{Y}=$ $-0.72+0.08 X$ dengan nilai akurasi 8.13 menggunakan MAPE. Arti persamaan regresi tersebut adalah sebagai berikut :

1. Setiap kenaikan variabel $X$ (periode) maka akan menaikkan variabel Y (penjualan batu marmer) sebesar 0,08 satuan, dengan asumsi variabel lain bernilai tetap. Artinya setiap tahun penjualan batu marmer akan meningkat 0,08 satuan.

2. Apabila nilai variabel $X$ (periode) dianggap 0 maka penjualan baru marmer adalah $-0,72$ satuan (sebesar nilai konstantanya).

Tabel 3 Perhitungan Batu Zeolite

\begin{tabular}{|c|c|c|c|c|c|}
\hline Periode & $\mathrm{X}$ & $\begin{array}{c}\text { Banyak } \\
(\mathrm{Y})\end{array}$ & $\mathrm{XY}$ & $\mathrm{X}$ & $\hat{Y}=\mathrm{a}+\mathrm{bX}$ \\
\hline \multirow{5}{*}{} & 13 & 2 & 26 & 169 & 0.37 \\
\cline { 2 - 6 } & 14 & 0 & 0 & 196 & 0.46 \\
\cline { 2 - 6 } & 15 & 1 & 15 & 225 & 0.54 \\
\cline { 2 - 6 } & 16 & 0 & 0 & 256 & 0.62 \\
\cline { 2 - 6 } & 17 & 0 & 0 & 289 & 0.71 \\
\cline { 2 - 6 } & 18 & 0 & 0 & 324 & 0.79 \\
\cline { 2 - 6 } & 19 & 1 & 19 & 361 & 0.88 \\
\cline { 2 - 6 } & 20 & 0 & 0 & 400 & 0.96 \\
\cline { 2 - 6 } & 21 & 2 & 42 & 441 & 1.04 \\
\cline { 2 - 6 } & 22 & 0 & 0 & 484 & 1.13 \\
\cline { 2 - 6 } & 23 & 1 & 23 & 529 & 1.21 \\
\cline { 2 - 6 } Total & 24 & 3 & 72 & 576 & 1.29 \\
\hline \multirow{2}{*}{} & 222 & 10 & 197 & 4250 & \\
\hline
\end{tabular}

Melalui grafik pada Gambar 12 jika perbedaan keduanya yang tidak terlalu jauh untuk dijadikan indikasi jika prediksi menggunakan metode linear regression cukup akurat. Grafik yang dihasilkan mengalami kenaikan setiap tahun penjualan batu marmer sebesar 0,08 satuan.

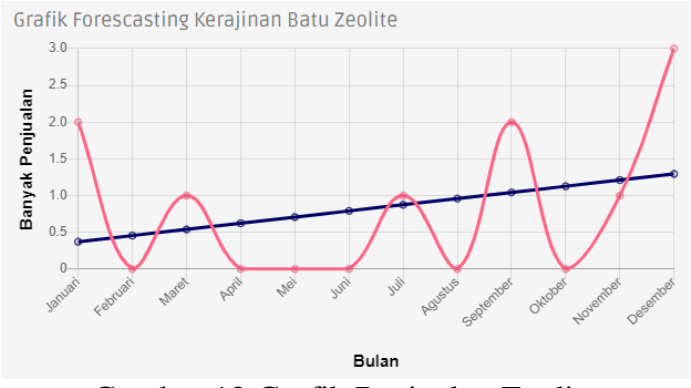

Gambar 12 Grafik Penjualan Zeolite

\subsection{Batu Andesit}

Pada Tabel 4 data penjualan untuk jenis batu andesit, dimana dimana nilai $\mathrm{X}$ kolom periode dan nilai $\mathrm{Y}$ banyaknya penjualan jenis batu andesit. Dengan menggunakan rumus pada persamaan 2.2 dan persamaan 2.3 didapat persamaan regresi $\hat{Y}=$ $-1.72+0.18 X$ dengan nilai akurasi $7.58 \%$ menggunakan MAPE. Arti persamaan regresi tersebut adalah sebagai berikut :

1. Setiap kenaikan variabel $X$ (periode) maka akan menaikkan variabel $\mathrm{Y}$ (penjualan batu marmer) sebesar 0,18 satuan, dengan asumsi variabel lain bernilai tetap. Artinya setiap tahun penjualan batu marmer akan meningkat 0,18 satuan.

2. Apabila nilai variabel $X$ (periode) dianggap 0 maka penjualan baru marmer adalah $-1,72$ satuan (sebesar nilai konstantanya).

Tabel 4 Perhitungan Batu Andesit

\begin{tabular}{|c|c|c|c|c|c|}
\hline \multirow{3}{*}{ Periode } & $\mathrm{X}$ & $\begin{array}{c}\text { Banyak } \\
(\mathrm{Y})\end{array}$ & $\mathrm{XY}$ & $\mathrm{XX}$ & $\hat{Y}=\mathrm{a}+\mathrm{bX}$ \\
\hline \multirow{5}{*}{} & 13 & 0 & 0 & 169 & 0.60 \\
\cline { 2 - 6 } & 14 & 0 & 0 & 196 & 0.78 \\
\cline { 2 - 6 } & 15 & 1 & 15 & 225 & 0.96 \\
\cline { 2 - 6 } & 16 & 0 & 0 & 256 & 1.14 \\
\cline { 2 - 6 } & 17 & 4 & 68 & 289 & 1.32 \\
\cline { 2 - 6 } & 18 & 0 & 0 & 324 & 1.49 \\
\cline { 2 - 6 } & 19 & 4 & 76 & 361 & 1.67 \\
\cline { 2 - 6 } & 20 & 5 & 100 & 400 & 1.85 \\
\cline { 2 - 6 } & 21 & 0 & 0 & 441 & 2.03 \\
\cline { 2 - 6 } & 22 & 0 & 0 & 484 & 2.21 \\
\cline { 2 - 6 } & 23 & 2 & 46 & 529 & 2.39 \\
\cline { 2 - 6 } & 24 & 3 & 72 & 576 & 2.56 \\
\hline Total & 222 & 19 & 377 & 4250 & \\
\hline
\end{tabular}

Melalui grafik pada Gambar 13 jika perbedaan keduanya yang tidak terlalu jauh untuk dijadikan indikasi jika prediksi menggunakan metode linear regression cukup akurat. Grafik yang dihasilkan mengalami kenaikan setiap tahun penjualan batu marmer sebesar 0,18 satuan. 


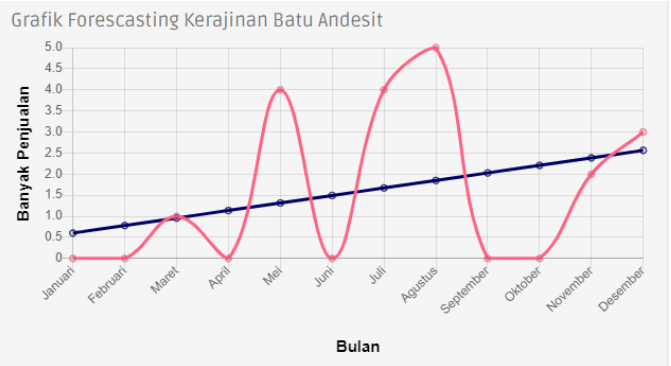

Gambar 13 Grafik Penjualan Batu Andesit

\subsection{Pengujian Keakurasian}

Setelah melakukan prediksi terhadap semua jenis batu pengujian keakurasian dilakukan untuk memastikan tingkat akurasi dari hasil perhitungan prediksi penjualan kerajinan batu menggunakan metode linear regression pada CV. Bukit Mulia. Pegujian keakurasian menggunakan MAPE (Mean Absolute Percentage Errorr) dapat dikategorikan baik karena nilai presentasi kurang dari $10 \%$ untuk jenis batu marmer, batu onyx, batu zeolite dan batu andesit. Tabel pengujian keakurasian seperti ditunjukkan pada Tabel 5.

Tabel 5 Pengujian Keakurasian
\begin{tabular}{|c|c|}
\hline Jenis Batu & $\begin{array}{c}\text { Ukuran Evaluasi } \\
\text { MAPE }\end{array}$ \\
\hline Marmer & $5.08 \%$ \\
\hline Onyx & $6.46 \%$ \\
\hline Zeolite & $8.13 \%$ \\
\hline Andesit & $7.58 \%$ \\
\hline
\end{tabular}

\subsection{Pengujian Fungsionalitas}

Pada pengujian Fungsionalitas sistem akan dilakukan percobaan untuk menguji semua fungsi yang ada di sistem, apakah sistem berfungsi dengan baik atau tidak. Pengujian dilakukan pada 2 browser web. Hasil dari pengujian fungsionalitas sistem dapat ditujukkan pada Tabel 6.

Tabel 6 Pengujian Fungsonalitas Sistem

\begin{tabular}{|l|c|c|}
\hline \multirow{2}{*}{ Fungsi } & \multicolumn{2}{c|}{ Browser } \\
\cline { 2 - 3 } & Microsoft Edge & Google Chrome \\
\hline Login & $\sqrt{ }$ & $\sqrt{ }$ \\
\hline Halaman Dashboard & $\sqrt{ }$ & $\sqrt{ }$ \\
\hline Data Batu & $\sqrt{ }$ & $\sqrt{ }$ \\
\hline Tambah Data Batu & $\sqrt{ }$ & $\sqrt{ }$ \\
\hline Ubah Data Batu & $\sqrt{ }$ & $\sqrt{ }$ \\
\hline Hapus Data Batu & $\sqrt{ }$ & $\sqrt{ }$ \\
\hline Data Kerajinan & $\sqrt{ }$ & $\sqrt{ }$ \\
\hline Tambah Data Kerajinan & $\sqrt{ }$ & $\sqrt{ }$ \\
\hline Ubah Data Kerajinan & $\sqrt{ }$ & $\sqrt{ }$ \\
\hline Hapus Data Kerajinan & $\sqrt{ }$ & $\sqrt{ }$ \\
\hline Data Penjualan & $\sqrt{ }$ & $\sqrt{ }$ \\
\hline Tambah Data Penjualan & $\sqrt{ }$ & $\sqrt{ }$ \\
\hline Ubah Data Penjualan & $\sqrt{ }$ & $\sqrt{ }$ \\
\hline Hapus Data Penjualan & $\sqrt{ }$ & $\sqrt{ }$ \\
\hline Forecasting & $\sqrt{ }$ & $\sqrt{ }$ \\
\hline Perhitungan & $\sqrt{ }$ & \\
\hline Grafik & & \\
\hline Logout & &
\end{tabular}

Keterangan :

$\sqrt{ }=$ Berjalan

$\mathrm{x}=$ Tidak berjalan
Berdasarkan Tabel 6 diketahui bahwa seluruh fungsi pada aplikasi forecasting yang dikembangkan dapat berjalan pada Microsoft Edge dan Google Chrome. Oleh karena itu, aplikasi forecasting dapat dijalankan dengan baik pada beberapa browser web.

\section{KESIMPULAN DAN SARAN}

\subsection{Kesimpulan}

Kesimpulan yang dapat penulis paparkan setelah melakukan peracangan prediksi penjualan kerajinan batu antara lain :

1. Berdasarkan langkah - langkah yang dilaksanakan diketahui aplikasi forecasting dapat dikembangkan melalui tahapan implementasi dari analisa dan perancangan.

2. Berdasarkan hasil pengujian fungsionalitas pada aplikasi forecasting dapat dijalankan dengan baik pada browser web.

3. Berdasarkan hasil pengujian user pada aplikasi forecasting sesuai dengan dengan harapan user dan dapat dipergunakan sebagai dasar untuk melakukan prediksi penjualan kerajinan batu pada CV. Bukit Mulia.

\subsection{Saran}

Untuk pengembangan aplikasi, terdapat beberapa saran untuk aplikasi forecasting penjualan kerajinan batu menggunakan metode linear regression berbasis web yaitu :

1. Penelitian selanjutnya bisa diprediksi menggunakan metode forecasting lain antara lain Metode Moving Average dan Exponential Smoothing.

2. Penelitian selanjutnya prediksi penjualan bisa dikembangkan dengan berbasis mobile menggunakan metode berbasis IoT.

\section{DAFTAR PUSTAKA}

[1] C. P. Navisha, 31 October 2017. [Online]. Available: https://www.dictio.id/t/bagaimanacara-melakukan-peramalan-penjualan/13613

[2] G. N. Ayuni and D. Fitrianah, "Penerapan Metode Regresi Linier Untuk Prediksi Penjualan Properti pada PT XYZ," Jurnal Telematika. 14(2), pp. 79-85, 2019.

[3] R. Zunaidhi, W. S. Saputra and N. K. Sari, "Aplikasi Peramalan Penjualan Menggunakan Metode Regresi Linier," SCAN. VII(3), pp. 4145, 2014

[4] P. Katemba and R. K. Djoh, "Pediksi Tingkat Produksi Kopi Menggunakan Regresi Linier," Jurnal Ilmiah Flash. 3(1), pp. 42-51, 2017

[5] H. Haryawan and C. Iswahyudi, "Teknik Peramalan Penjualan Sepeda Motor Dengan Menggunakan Metode Regresi Linier Sederhana Pada CV. NIAGA PRATAMA MOTOR," STIKOM BALI, Bali, 2015

[6] M. Marbun, H. T. Sihotang and M. A. Nababan, "Perancangan Sistem Peramalan Jumlah Wisatawan Asing," Jurnal Mantik Penusa. 2(1), pp. 41-49, 2018 
[7] Harliana and A. Syafrianto, "Prediksi Jumlah Pendaftaran Calon Mahasiswa Baru Dengan Metode Regresi Linier," Jurnal Ilmiah DASI. 18(3), pp. 1-5, 2017

[8] A. Gunawan, "Penerapan Data Mining," 2020. [Online].

Available: https://www.coursehero.com/file/67855896/PE NERAPAN-DATA-MININGdocx/

[9] U. D. Nuswantoro, "BAB 2 TINJAUAN PUSTAKA," [Online]. Available: http://eprints.dinus.ac.id/23366/11/bab2_20543. pdf.

[10] K. Margi S and S. Pendawa W, "Analisa Penerapan Metode Single Exponential Smoothing Untuk Prediksi Penjualan Pada Periode Tertentu (Studi Kasus : PT. Media Cemara Kreasi)," Prosiding SNATIF, pp. 259266, 2015. 